\title{
黎明期のレーザープラズマ相互作用研究
}

\author{
山中 龍彦
}

\section{Laser Plasma Interaction Research in Early Stage of Laser Fusion}

\author{
Tatsuhiko YAMANAKA ${ }^{\dagger}$ \\ (Received November 9, 2009)
}

\begin{abstract}
Reviewed are the laser plasma interaction researches which were performed by the author in 1970s. The anomalous absorption is discovered by irradiating $10 \mathrm{GW}-2$ ns pulse from one beam glass laser system on to the deuterium solid targets. The absorption mechanism is identified to be the parametric decay instability. Scattered light from irradiated targets was intensively studied to be found the ion acoustic wave excited parametrically, and also is found the laser beam self-focusing due to the Ponderomotive force. The anomalous transmission of laser light is observed in the polyethylene films back-coated with thin metal film when pico-seconds high intensity laser of above $10^{14} \mathrm{~W} / \mathrm{cm}^{2}$ is irradiated. This effect had triggered the fast ignition idea by me.
\end{abstract}

Key Words: Laser plasma interaction, Anomalous absorption, Scattered light from plasma, Anomalous transmission of light, Self-focusing

1. はじめに

レーザーとプラズマとの相互作用の研究は，それ自 体, 今まで経験することがなかった領域への取り組みで あると共に1962年にN. G. Basov, O. N. Krokhin ${ }^{1)} に よ り$ 提案され，1963年にJ. M. Dowsonによりその可能性を定 量的に取り扱われたレーザー核融合への道筋を明らかに するための第一歩である. 筆者は, 大学院修士課程の学 生であった1964年よりレーザー核融合研究の遂行のため に, 高出力レーザー開発研究を進めながら， $Q$ スイッチ レーザーによる気体, 固体プラズマ生成の研究を進めて きた. 1969年, 名古屋大学プラズマ研究所(核融合科学 研究所の前身)の客員教授として同所でレーザー核融合 の研究に本格的に着手されることになった山中千代衛 先生の助手としてレーザープラズマの研究を本格的に展 開することになった。ここでは, 大阪工業試験所, 三菱 電機, 旭ガラス, 指月電気, ウシオ電機の協力を得て 1970年3月に完成させることが出来た我が国初の大型 レーザーである「激光 $\mathrm{I}$ 号」ガラスレーザー（出力 $50 \mathrm{GW}$, 1ビーム5段増幅)を用いて行った1970年代のレーザープ ラズマ相互作用研究を中心に記したい.

\section{2. 異常吸収の発見}

核融合でエネルギーを取り出すためには，1億度近い 温度まで然料を加熱する必要がある。当時, 我々が持っ ていた知識は, レーザーによるプラズマの加熱もマイク 口波放電と同様, 電磁波で振られた電子とイオンのクー ロン衝突を介して起こり, 吸収係数は電子温度の -3/2乗に比例して減少すると云うものであった。 この 吸収過程では, 固体密度プラズマに於いても数 100 万度 までの加熱がせいぜいである，そのため，当初よりプラ ズマの集団運動である電子プラズマ波やイオン音波との 相互作用を介しての非線形加熱機構を初めとするレー ザーとプラズマの非線形相互作用の理論研究が活発に行 われていた。

このような状況下, 我が国初の大出力ガラスレーザー 「激光 $\mathrm{I}$ 号」よりの $10 \mathrm{GW}, 2 \mathrm{~ns}$ パルスの固体重水素夕ー ゲット $(2 \mathrm{~mm}$ 角，長さ〜 $10 \mathrm{~mm})$ への照射実験で, 1971 年7月，104個のDD核融合中性子の発生に成功した。 そ して, 中性子が発生するレーザー強度 $10^{13} \mathrm{~W} / \mathrm{cm}^{2}$ 以上で は, 電子温度 $T_{e}$ のレーザー強度依存性がそれ以下での $T_{e} \propto P^{0.6}$ から急勾配の $T_{e} \propto P^{1.2}$ へと変わり，高速イオンが 発生, 反射率も $10^{14} \mathrm{~W} / \mathrm{cm}^{2} よ り$ 顕著に低下することが明 らかになった。これは待望されていた異常吸収の発見で

\footnotetext{
${ }^{\dagger}$ 大阪大学 名誉教授, 福井工業大学 ( $\overline{7} 910-8505$ 福井県福井市学園3-6-1)

${ }^{\dagger}$ Professor Emeritus, Osaka University, Fukui University of Technology, 3-6-1 Gakuen, Fukui-shi, Fukui 910-8505
} 


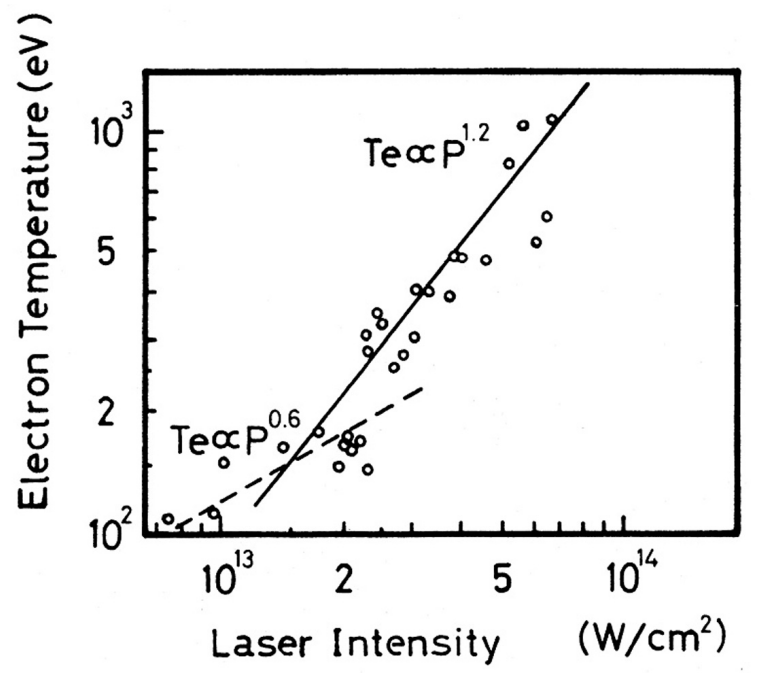

Fig.1 Irradiated laser intensity dependence of electron temperature of deuterium plasma measured by $\mathrm{x}$-ray absorption method. Temperature increases with steep slope above $10^{13} \mathrm{~W} / \mathrm{cm}^{2}$. This is the first observation of anomalous absorption.

あった。 また, 固体重水素ターゲットでの核融合中性子 の発生は，1970年に発表されたフランスのF. Floux等3)の 成果に次ぐもので, 名古屋大学のへリウム液化装置の オーバーホールの期間で液体へリウム陸揚所の横浜より

取り寄せて実験を行っていた時であった。

この中性子の発生を伴う急激な電子温度の上昇や高工 ネルギーイオンの発生のしきい值は, 西川恭治氏の提 唱した, 遮断密度領域でレーザー光が電子プラズマ波と イオン音波に崩壊するパラメトリック崩壊不安定性の理

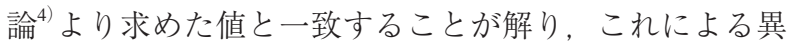
常加熱であると結論, Physics Letters, 日米セミナー(京 都, ’72.9), Physical Review A等 ${ }^{5}$ に発表することがで きた。

\section{3. 散乱光による相互作用の研究}

直径 $1 \mathrm{~mm}$ 以下で, かつ固体密度近傍のプラズマ中の 現象は, 測定器を挿入して直接測定することは困難であ る.それゆえ，レーザープラズマの研究はプラズマより の散乱光や放射等を調べるパッシブな方法が常套手段と して用いられていた。この散乱光の研究を通して以下の ことを明らかにすることができた。

\section{1 パラメトリック不安定性の検証}

ガラスレーザーよりもスペクトル幅の狭いYAGレー ザーを発振器として, イオン質量の異なる水素 $\mathrm{H}_{2}$, 重 水素 $\mathrm{D}_{2}$ ターゲットを照射, 遮断密度点で発生する2倍高 調波域のスペクトル観測を行った。その結果, Fig. 2に 示すように2倍高調波の赤方にイオン質量に関係しない 電子プラズマ波によるピークとイオン質量に依存するイ オン音波によるピークを観測, パラメトリック崩壊不安 定性の発生を，直接，確認することができた6).

また, YAGレーザーとスペクトル幅の広いガラス

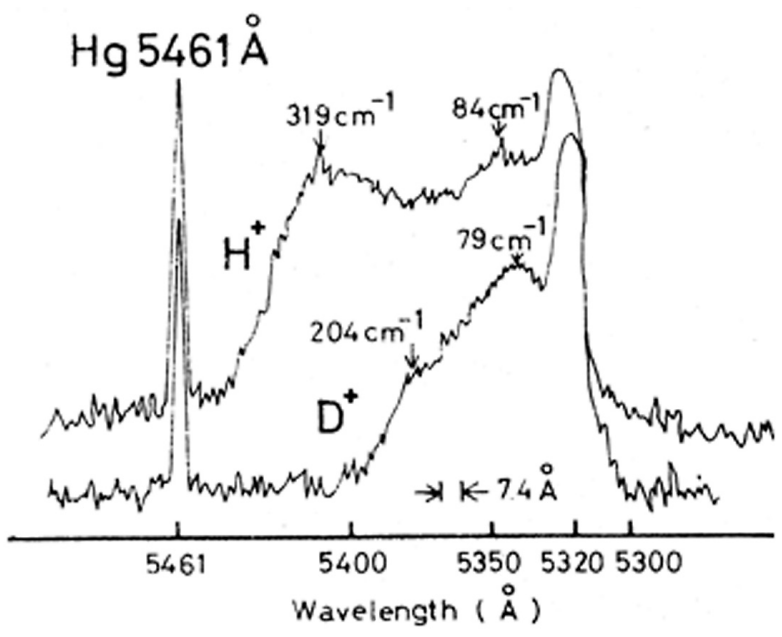

Fig. 2 Spectrum of backscattered light around the second harmonic light when $\mathrm{H}_{2}$ and $\mathrm{D}_{2}$ solid targets are irradiated by the narrow band YAG laser system. Observed red shifted two peaks correspond to the modulation by the electron plasma wave and the ion acoustic wave, respectively, produced by the parametric decay instability.

レーザー発振器の両者を用いて加熱実験を行った結果, ガラスレーザーの場合の方が異常加熱の発生しきい值が 低下することを見出し，イオン音波の周波数の 2 倍の ビート周波数成分が励起光に含まれているとパラメト リック崩壊不安定性の間值が低下するという西川氏等の “Parametric Double Resonance”の理論 ${ }^{7}$ を検証することが できた。

\section{2 プラズマ中でのレーザー光の自己集束}

誘電体中にレーザー光を集光すると3次の非線形効果 による自己集束が起こることは実験的にもよく知られた 現象である。1よりも小さい屈折率を持つプラズマ中で この現象が起こると，1972年にJ. Nuckollus等 ${ }^{8)}$ により発 表された懪縮核融合での圧縮の一様性を阻害する可能性 がある。このことを念頭に置き, ターゲットの固体 $\mathrm{H}_{2}$, $\mathrm{D}_{2}$ ヘのレーザー集光位置を変化させて散乱光スペクト ルの角度分布およびその時間分解計測を行った結果，特 定のレーザー集光条件下で, 動重力 (ポンデロモーチブ 力）によりプラズマが排除された結果生ずるレーザー光 の自己集束を初めて観測することができた ${ }^{9)}$.

この実験では，散乱光をビディコンで取り込んだスぺ クトル強度分布をオッシロスコープ上に表示するシステ ムおよび出口を4チャンネルに分割した像転送光ファイ バに高速応答バイプラナ光電管を接続したシステムを開 発，それぞれ時間積分スペクトル計測，時間分解スペク トル計測に用いた

入射光の偏光方向およびレーザー集光位置を変えて入 射光波長域の散乱光を後方 $0^{\circ}, 45^{\circ}, 90^{\circ}$ 方向で測定し た結果，照射強度が $10^{14} \mathrm{~W} / \mathrm{cm}^{2}$ 以上で且つレーザー集光 位置がターゲットの初期表面位置より 50-150 mm $\left(\mathrm{H}_{2}\right.$ ターゲット) 前方の時のみ, 偏光方向に関係なく後方散 乱光のみに青方シフト光が観測された。この青方シフト 
光は入射光のピークより立ち上がり, 入射光と共に消滅 した(Fig. 3参照).

この実験で始めて観測された青方シフト光の発生は以 下のように説明できる，入射光パルスの前半で自己集束 が起こり，そのポンデロモーチブカによるプラズマの排 除で密度の低下したチャンネルが形成される。レーザー 強度が低下するパルス後半ではポンデロモーチブカが減 少する結果，チャンネル部の密度が上昇に転ずる。この 密度上昇時に生ずる位相の時間变化による青方シフトで

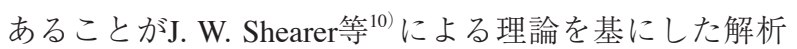
の結果判り，プラズマ中でのレーザー光の自己集束であ るとの結論を得た。

\section{4. 光子圧による密度変調}

レーザーの吸収率はプラズマの密度勾配に依存する。 密度勾配が急峻になるとクーロン衝突による古典吸収や パラメトリック崩壊不安定性による吸収効率は減少す る. 密度勾配に対して斜めにp偏光ビームが照射すると， ビームは遮断密度近傍で折り返しスペキュラー反射す

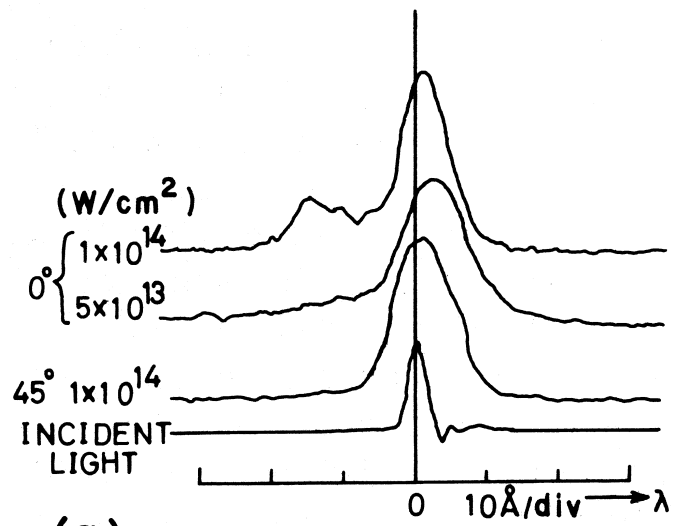

(a)

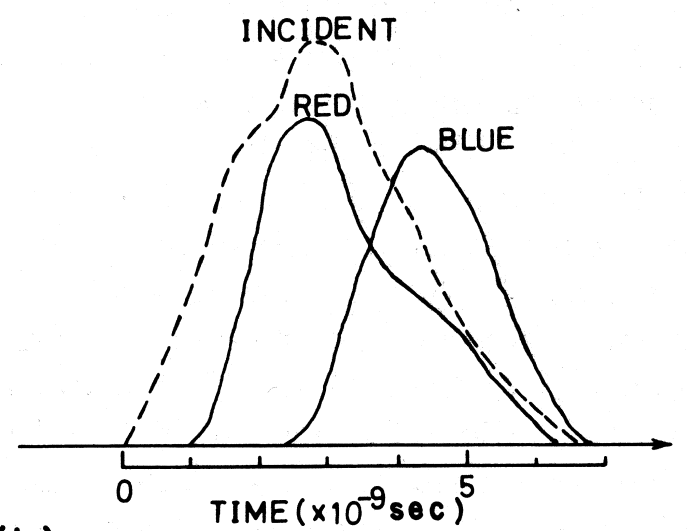

(b)

Fig. 3 Spectra of backscattered light around the irradiated light spectrum. (a); the time integrated spectra. The blue shifted spectrum is observed above the intensity of $10^{14} \mathrm{~W} / \mathrm{cm}^{2}$. (b); the temporal change of the spectra at intensity of above $10^{14} \mathrm{~W} / \mathrm{cm}^{2}$. The blue shifted light appears behind the peak of the irradiated pulse which is due to the temporal phase change of the plasma channel induced by Ponderomotive force.
る。折り返し点ではレーザーの電界方向が密度勾配の方 向と一致する。密度勾配が急峻になるとレーザー電界は 遮断密度点まで達し，共鳴的に電子プラズマ波を励起す る共鳴吸収 ${ }^{11)}$ が支配的となる。

高強度照射時での生成プラズマの遮断密度近傍での密 度変調 (スティープニング)の有無を調べるために1974年 に完成した「激光II号」 2 ビームレーザーよりの $30 \mathrm{ps}$ パル スを，ガラスマイクロバルーンをターゲットとして対向 照射した。照射強度は左側 $10^{15} \mathrm{~W} / \mathrm{cm}^{2}$ ，右側 $10^{16} \mathrm{~W} / \mathrm{cm}^{2}$ である。遮断密度近傍での密度勾配の時間変化をレー ザー顕微干渉計およびシュリーレン法で測定した。プ ローブ光には照射ビームの一部を抜き出して波長変換し た530 nm光を用いた。観測計の時間，空間分解能はそ れぞれ $30 \mathrm{ps}, 2 \mu \mathrm{m}$ である。照射強度 $10^{16} \mathrm{~W} / \mathrm{cm}^{2}$ 側で光子 圧による密度勾配の急峻化を観測 (参照Fig. 4), 高密度 爆縮に必要なレーザー照射強度化では共鳴吸収が重要な 役割を果たすことを示すことができた ${ }^{12)}$.

\section{5. 高Z薄膜ターゲットでの異常透過現象}

爆縮核融合研究の進展の結果, 現在では爆縮時のレイ リー・テイラー流体不安定性の抑制の観点からDT固体 燃料とアブレーターとしても働く薄いプラスチック層よ りなる2層構造ターゲットが良いとされている。しかし， 初期の段階では異常加熱で発生した高エネルギー電子に よる燃料の先行加熱の抑制と爆縮燃料の長時間保持の観 点から，燃料とプラスチックアブレーター(低Z層)の間 に質量密度の高い金属層(高Z層)をタンパーとして配す る3層構造が提案されていた。このターゲットでのエネ ルギー輸送を調べるためにアブレーター・タンパー構造 を模したプラスチック $(4 \mu \mathrm{m}$ 厚) と金属 $(1.25-2.5 \mu \mathrm{m}$ 厚の

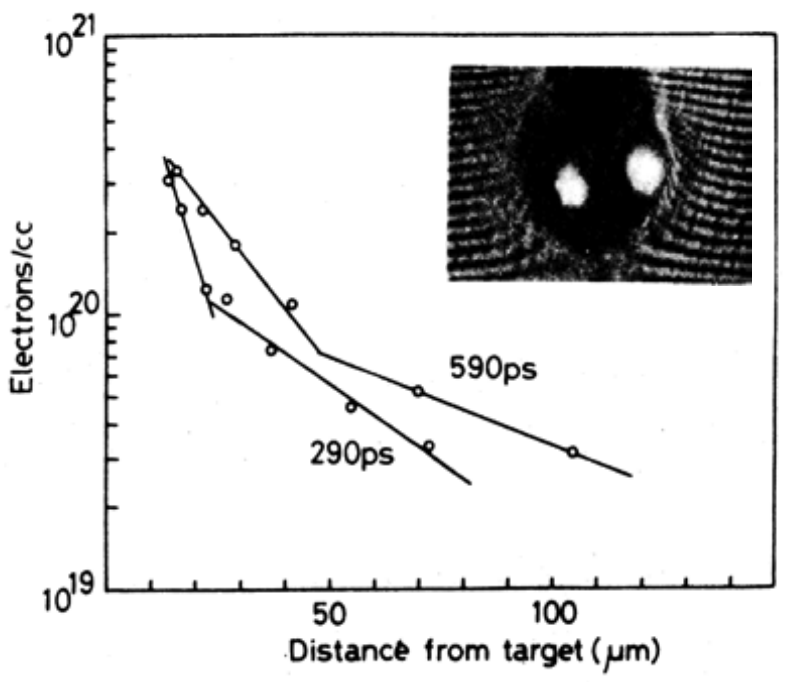

Fig.4 Temporal change of axial density profile when $10^{16} \mathrm{~W} / \mathrm{cm}^{2}$ laser is irradiated to the glass microballoon. The density gradient is steeper at the higher density region, and gradient decrease with decreasing the laser intensity in the pulse. The inserted picture is the interferograph of laser irradiated target. Diameter of glass microballoon is $50 \mu \mathrm{m}$. 


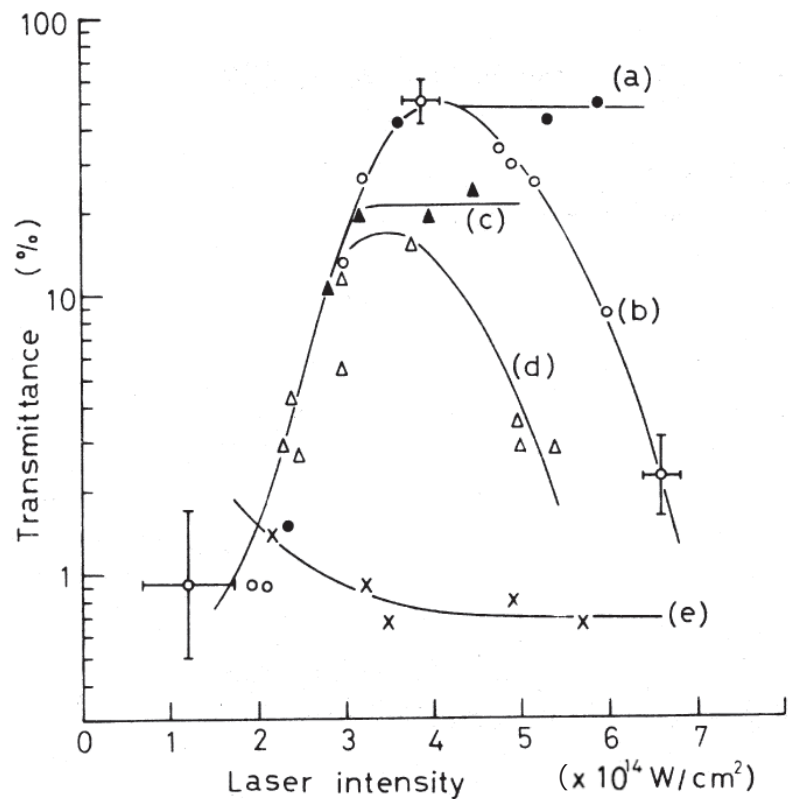

Fig. 5 Transmittances of laser light as a function of the incident laser intensity. Irradiated targets are curve (a); $2.5 \mu \mathrm{m} \mathrm{Ni} \mathrm{foil,} \mathrm{curve} \mathrm{(b);} 2.3 \mu \mathrm{m} \mathrm{Ni}$ foil plated on $4.0 \mu \mathrm{m}$ polyethylene film, curve (c); $1.25 \mu \mathrm{m} \mathrm{Ni}$ foil curve (d); $1 \mathrm{~mm} \mathrm{Ni}$ foil plated on $4 \mu \mathrm{m}$ polyethylene film, and curve (e); $\mu$ m polyethylene film. Laser is irradiated from the polyethylene side for every target. The metal coated targets showed anomalous transmittance.

ニッケル)よりなる2層構造ターゲットを，異常加熱によ る高エネルギー電子を多量に発生する半值幅 (FWHM) $160 \mathrm{ps}$ の高強度パルスを $45^{\circ}$ 方向より照射する実験を 行った。得られた結果をFig. 5に示す。図より分かるよ うに厚さ $4 \mu \mathrm{m}$ の単純ポリエチレンでの後面への透過率 が10\%程度であるのに対して金属で裏打ちしたター ゲットでは後面への透過率が異常に高くなる現象を発見 した. 照射レーザー強度は増幅器の励起入力を変化させ ることで行ったため, 高励起下での増幅器からの強い ASEやプレパルス強度の増加等の異常透過の原因になる 効果を調べたが, 総て排除された。この異常透過現象は 高エネルギー電子と高ZプラズマよりのX線放射の輸送 で説明ができ, 1977年, Phys. Rev. Lett.に報告した ${ }^{13)}$. これは，筆者が1983年に提案した「爆縮プラズマを 40 TWのピコレーザーで加熱すると, 発生する高エネル ギー電子でコアープラズマを $5 \mathrm{keV}$ 過熱できる」 ${ }^{14)}$ と云う 高速点火の発想に繋がった実験結果である.
6. むすび

我々による異常加熱の発見をきっかけに，国際会議 “Conference on Anomalous Absorption”が米国でスタート, 以降，活発な研究が展開されるようになった。パラメト リック不安定性による異常加熱は密度勾配がスティープ になると発生のしきい值が上昇する。その後の研究の結 果，密度勾配がスティープになる核融合実験でのレー ザー条件では，主たる異常過熱機構は共鳴吸収が主役と なることが明らかにされた。

さらに，爆縮実験の進展の結果，異常加熱により発生 する高エネルギー電子は，爆縮時の燃料の先行過熱を誘 起するため好ましくないとの認識が共有され，異常過熱 を伴わない条件での爆縮が追求され，短波長レーザーが 使用されるようになった。

現在, 活発に研究が進められている極短パルス超高強 度レーザーと物質との相互作用研究でいくつかの新しい 現象が発見されているが，そんなことが起こるのかと云 うような現象を提起してくれるであろうと期待してい る.

\section{参考文献}

1) N. G. Basov and O. N. Krokhin: Proc. the Conference on Quantum Electronics, Paris (1963).

2) J. M. Dowson: Phys. Fluid 7 (1964) 981.

3) F. Floux, D. Congnard, et al: Phy. Rev. A 1 (1970) 821.

4) K. Nishikawa: J. Phys. Soc. Jpn 24 (1986) 916; ibid 24 (1968) 1152.

5) C. Yamanaka, T. Yamanaka, et al: Phys. Lett. 38A (1972) 495 ibid Phys. Rev. A 6 (1972) 2335.

6) C. Yamanaka, T. Yamanaka, et al: Phys. Rev. Lett. 32 (1974) 1038.

7) D. Arnush, B. Fried, C. Kennel, K. Nishikawa, et al: UCLA Rep. No. PPG139 (1972) unpublished.

8) J. Nuckolls, L. Wood, A. Thiessen, and G. Zimmerman: Nature 239 (1972) 139

9) C. Yamanaka, T. Yamanaka, et al: Phys. Rev. A 11 (1975) 2138.

10) J. W. Shearer and J. L. Eddleman: Phys. Fluids 16 (1973) 1753.

11) V. L. Ginzburg: Propagation of Electromagnetic Wave in Plasmas (Pergamon Press, New York, 1970).

12) H. Azechi, S. Oda, K. Tanaka, T. Sasaki, T. Yamanaka, and C. Yamanaka: Phys. Rev. Lett. 39 (1977) 1144.

13) J. Mizui, N. Yamaguchi, T. Yamanaka, and C. Yamanaka: Phys. Rev. Lett. 39 (1977) 619.

14）山中 龍彦：大阪大学レーザー核融合研究センター「金剛計 画 (第1期) 検討作業報告書別冊」(1983) p.5. 